\title{
NEW PERSPECTIVES ON \\ METHODOLOGY IN GARDEN HISTORY: APPROACHES TOWARDS WRITING ABOUT IMPORTED MEDICINAL PLANTS IN COLONIAL NEW ZEALAND
}

\section{Abstract}

This paper demonstrates how combining methodological approaches from garden history and medical history can present new perspectives on the history of gardens and health in colonial New Zealand, and recover the prominent associations between health and the environment in settler society within the context of modern historical research. It appeals to researchers to 'cast their net wide' when searching for source material, an approach that situates the study of medicinal plants within a wider, interdisciplinary historiographical framework.

Keywords: garden history, methodology, medicinal plants

\section{Introduction}

Garden histories of colonial New Zealand first appeared in the 1930s, but lacked academic rigour given the infancy of the discipline. ${ }^{1}$ Only really from the $1980 \mathrm{~s}$ has a handful of rich and regionally specific studies been produced. ${ }^{2}$ Supported by a number of prominent researchers, garden history in New Zealand has subsequently grown into a small but multi-disciplinary field

1 Robert Nairn, 'The Early History of Horticulture in New Zealand', Supplement to the Journal of the Royal Society of Horticulture 3, no. 2 (1932); Alan Hale, Pioneer Nurserymen of New Zealand (Wellington: A. H. and A. W. Reed, 1955); M. J. Barnett, H. G. Gilpin, and Clarence J. Metcalf, A Garden Century: The Christchurch Botanic Gardens, 1863-1963 (Christchurch: Christchurch Botanic Gardens, 1964).

2 This scholarship is summarised in James Beattie, 'The Empire of the Rhododendron: Reorienting New Zealand garden history', in Making a New Land: Environmental Histories of New Zealand, ed. Tom Brooking and Eric Pawson, 2nd ed. (Dunedin: Otago University Press, 2013), 241-57; James Beattie and Katie Holmes, 'Reflections on the history of Australasian gardens and landscapes', Studies in the History of Gardens \& Designed Landscapes 31, no. 2 (2011): 75-82. 
that examines a wide range of topics, including the exchange of plants and botanical information, the impetus for garden-making, and the iconography and symbolism of gardens. ${ }^{3}$ Despite the diversity of the subject matter, very little has been written on the methodologies employed by New Zealand garden historians up till now. ${ }^{4}$

Through a case study of health and gardens, this article contributes to the broader examination of garden historical methodology by discussing the benefits of a multi-source and multi-disciplinary approach in writing the history of medicinal plants in New Zealand. Specifically, it explores the advantages of using a variety of source materials in combination with methodological approaches drawn from garden history and medical history.

A history of medicinal plants in colonial New Zealand re-establishes links between health and the environment in the context of modern historical research. It offers new perspectives on environmental change in New Zealand and colonial medical culture by asking historians to explore the motivations for introducing, cultivating, and distributing medicinal plants during the nineteenth and early twentieth centuries and to consider the medicines and medicaments that played such an important role in the history of health. In addition, it appeals to researchers to explore health-related interactions between Māori and European in colonial New Zealand.

This paper begins by accounting for the absence of medicinal plants from New Zealand's garden and medical historiography, and then provides a discussion of a variety of different primary sources as a means of connecting these two subject areas.

3 Prominent works include Matthew Bradbury, ed., A History of the Garden in New Zealand (Auckland: Viking, 1995); Helen Leach, 1000 Years of Gardening in New Zealand (Wellington: A. H. \& A. W. Reed, 1984); Matt Morris, 'A History of Christchurch Home Gardening from Colonization to the Queen's visit: Gardening culture in a particular society and environment' (PhD diss., University of Canterbury, 2006); Beattie and Holmes, 'Reflections on the history of Australasian gardens'; examples of its diversity include John Dwyer, 'Weeds in the Victorian Colonial Garden 1800-1860', Studies in Australian Garden History 2 (2006): 1-23; Ian Hoskins, "It is inevitably a people's park": Ceremony and democratic sentiment at the opening of Centennial Park, 1888', Studies in Australian Garden History 1 (2003): 55-70; Duncan Campbell, 'Transplanted Gardens: Aspects of the design of the Garden of Beneficence, Wellington, New Zealand', Studies in the History of Gardens \& Designed Landscapes 31, no. 2 (2011): 160-6; James Beattie 'Making Home, Making Identity: Asian Garden-Making in New Zealand, 1850s-1930s', Studies in the History of Gardens \& Designed Landscapes 31, no. 2 (2011): 139-59; Matt Dallos, 'Seeing Landscape: Geography, Autobiography, and Metaphor', Studies in the History of Gardens \& Designed Landscapes 34, no. 2 (2014): 146-50.

4 An exception to this omission is Beattie, 'The Empire of the Rhododendron', 241-57. 


\section{Garden history and medical history: A combined approach}

In modern western academic contexts, the study of medicinal plants is typically divided into scientific or social-scientific studies of individual species. The first commonly focuses on the plant's 'discovery', before examining its chemical constituents and synthetic modification, while the second provides histories of specific institutions, disciplines, or philosophies, and their founders, advocates, and achievements. ${ }^{5}$ In addition, self-help herbal guides often include a generic history of medicinal plants, but the information presented is typically divorced from its social context, or designed simply to promote a growing resistance to modern pharmaceuticals. ${ }^{6}$ In New Zealand, research on medicinal plants has followed a similar trajectory, with biochemical analyses of native medicinal plants and their constituents, and medical histories that focus on public institutions, such as providers of public health. ${ }^{7}$ The absence of medicinal plants in New Zealand's medical and garden historiography is arguably a consequence of this division of scholarly knowledge.

5 Suzanne Taylor and Virginia Berridge, 'Medicinal Plants and Malaria: An historical case study of research at the London School of Hygiene and Tropical Medicine in the twentieth century', Transactions of the Royal Society of Tropical Medicine and Hygiene 8 (2006): 707-14; Felipe Fernández-Armesto and Benjamin Sacks, 'The Global Exchange of Food and Drugs', in The Oxford Handbook of the History of Consumption, ed. Frank Trentmann (Oxford: Oxford University Press, 2012), 127-45; Joanne Birch, 'A Comparative Analysis of Nineteenth Century Pharmacopoeias in the Southern United States: A case study based on the Gideon Lincecum Herbarium', Economic Botany 63, no. 4 (2009): 427-40; Frank Dikötter, Lars Laaman, and Xun Zhou, 'China, British Imperialism and the Myth of the Opium Plague', in Drugs and Empires: Essays in Modern Imperialism and Intoxication, c. 1500 - c. 1930, ed. James H. Mills and Patricia Barton (Basingstoke: Palgrave Macmillan, 2007), 19-39. Outside New Zealand, historians have produced a number of histories of specific plants, such as the history of the opium poppy and reports on localised herbal systems that provide some analysis and exception to this trend. For example, R. Cambie and J. Ash, Fijian Medicinal Plants (East Melbourne: CSIRO, 1994); Martin Booth, Opium: A History (London: Simon \& Schuster, 1996); Leslie Taylor, The Healing Power of Rainforest Herbs: A Guide to Understanding and Using Herbal Medicines (New York: Square One, 2005); W. Arthur Whistler, Samoan Herbal Medicine: 'o lā'au ma vai fofōo o (Hawaii: Isle Botanica, 1996); Paul Petard, Raau Tahiti: The Use of Polynesian Medicinal Plants in Tahitian Medicine (Noumea, New Caledonia: South Pacific Commission, 1972).

6 Literally hundreds of herbal manuals have been published since the revival of western herbalism in the 1970s. Most include a generic global history of medicinal plants. For example, Barty Phillips, The Book of Herbs: An Illustrated A-Z of the World's Most Popular Culinary and Medicinal Plants (London: Arcturus, 2007); Deni Brown, The Royal Horticultural Society Encyclopedia of Herbs and their Uses: The Definitive A-Z Guide to Herbs (London: Dorling Kindersley Limited, 2002); Ben-Erik Van Wyk and Michael Wink, Medicinal Plants of the World: An illustrated scientific guide to important medicinal plants and their uses (Pretoria, South Africa: Briza, 2004); Antoine Al-Achi, An Introduction to Botanical Medicines: History, Science, Uses, and Dangers (Westport, CT: Praeger, 2008); Frank Lipp, Herbalism (London: Macmillan in association with Duncan Baird, 1996).

7 S. G. Brooker, R. C. Cambie, and R. C. Cooper, New Zealand Medicinal Plants (Auckland: Heinemann, 1981); Christina Macdonald, Medicines of the Māori: From their Trees, Shrubs, and other Plants, Together with Foods from the Same Sources (Auckland: Collins, 1973); Derek Dow, Safeguarding the Public Health: A History of the New Zealand Department of Health (Wellington: Victoria University Press, 1995); Frances Sydney Maclean, Challenge for Health: A History of Public Health in New Zealand (Wellington: Government Printer, 1964). 
Yet the connection between medical and garden writing is remarkably longlived and significant. In the West, from antiquity, scholars such as Hippocrates recognised the integral relationship between the environment and human health, and connections among particular environments and sickness and wellness. ${ }^{8}$ By the eighteenth century, scientific discoveries, investigation, and understanding drove the introduction into and use of medicinal plants in newly founded colonies. Anxieties relating to health and wellness in specific colonial settings, when combined with existing medical knowledge, led to conclusions about certain environments and the medicinal virtues of specific plants. ${ }^{9}$ Nineteenth-century New Zealand settlers expressed similar ideas as they chose seemingly healthful environments and climates in which to live and created 'green spaces' - parks and village greens - conducive to healthy living. Indeed, in nineteenth-century New Zealand, 'urban settlements - as much as rural areas - were important sites for debates about environmental change and human health'. ${ }^{10}$ The desire to stay healthy and create healthy environments in the young colony was among the motivations for introducing plants to New Zealand during European colonisation. ${ }^{11}$ But, with the exception of scholarship by James Beattie and the author, despite its importance, examination of medicinal plants or plants considered by colonists to be conducive to health is largely absent from garden historical scholarship. ${ }^{12}$ A focus on medicinal plants brings health-related motivations into clarity and demonstrates how, as Beattie notes, 'in nineteenth-century settler culture, landscape and vegetation figured as more than simply backdrops to human affairs'.$^{13}$

Up till now, New Zealand garden and environmental historians have concentrated on the themes of making home, of reshaping the land, and of colonisation in general. Many of these historians turn the lens towards the environment and examine the networks through which plants moved, but have largely overlooked the influence of health and perceptions of healthy environments,

8 Hippocrates posited the humoral theory of disease that decreed that good health relied on maintaining a balance of four bodily constituents or humours: blood, phlegm, black bile, and yellow bile. These humours were thought to exist in equilibrium and in relation to external elements such as climate, seasons, and celestial bodies, as well as internal processes such as age and emotion. Ill health of body or mind reflected an imbalance of humours and could be consequently restored by addressing the imbalance. Roberta Bivins, Alternative Medicine? A History (Oxford: Oxford University Press, 2007), 9; G. Foster and B. Anderson, Medical Anthropology (New York: John Wiley and Sons, 1978), 51-66; Vivian Nutton, 'Humoralism', in Companion Encyclopedia of the History of Medicine, vol. 1, ed. W. F. Bynum and Roy Porter (London: Routledge, 1993), 281-2.

9 James Beattie, Empire and Environmental Anxiety: Health, Science, Art and Conservation in South Asia and Australasia, 1800-1920 (Basingstoke: Palgrave Macmillan, 2011).

10 James Beattie, 'Colonial Geographies of Settlement: Vegetation, Towns, Disease and Well-Being in Aotearoa/New Zealand, 1830s-1930s', Environment and History 14, no. 4 (2008): 583-610.

11 Beattie, 'Colonial Geographies of Settlement', 583-610.

12 Beattie, 'Colonial Geographies of Settlement'; Joanna Bishop, 'The Role of Medicinal Plants in New Zealand's Settler Medical Culture, 1850s-1920s' (PhD diss., University of Waikato, 2014).

13 Beattie, 'Colonial Geographies of Settlement', 584. 
prominent factors and ideas in colonists' lives. ${ }^{14}$ Medical historians have similarly overlooked connections between health and environment. Moreover, until recently, medical historians in New Zealand have largely ignored lay or domestic healers and herbalists, and rarely mentioned medicinal plants. A focus on professional practitioners has largely sidelined analysis of domestic health practices and relationships, while cooperation among healers is only rarely discussed.

Instead, medical history in New Zealand has followed a trajectory characterised by an initial emphasis on the achievements of male doctors, to an account of public health services and institutions, and more recently, critically informed social and cultural historical research that incorporates elements of class, gender, and race in its analysis. ${ }^{15}$ During the 1950s and 1960s, scholarship was dominated by autobiographies written by mainly rural doctors for an audience drawn to the image of community service and colonial hardship. ${ }^{16}$ With doctors in the dominant role, plants appear only rarely as adjuncts to anecdotes and the heroic work of the medical practitioners themselves. The 1960s, an era of institutional health histories, was marked by the work of Frances Sydney Maclean, which addressed the role of the state and public health policy in

14 International historians have addressed the connection between health and environment. For example, Londa Schiebinger, Plants and Empire: Colonial Bioprospecting in the Atlantic World (Cambridge, MA: Harvard University Press, 2007). Richard Drayton discusses medicinal plants in relation to the creation of botanical gardens and economic botany in his Nature's Government: Science, Imperial Britain, and the 'Improvement' of the World (New Haven, CT: Yale University Press, 2000), 6-19, 26-30.

15 Robert Valpy Fulton, Medical Practice in Otago and Southland in the Early Days. A Description of the Manner of Life, Trials, and Difficulties of some of the Pioneer Doctors, of the Places in which, and of the People among whom, they Laboured (Dunedin: Otago Daily Times and Witness Newspapers Co., 1922); D. Macdonald Wilson, A Hundred Years of Healing: Wellington Hospital, 1847-1947 (Wellington: A. H. \& A. W. Reed, 1948); F. O. Bennet, Hospital on the Avon: The History of the Christchurch Hospital, 1862-1962 (Christchurch: North Canterbury Hospital Board, 1962); Sir Charles Hercus and Sir Gordon Bell, The Otago Medical School under the First Three Deans (Edinburgh: E. \& S. Livingstone, 1964); Laurie Gluckman, Tangiwai: A Medical History of New Zealand prior to 1860 (Christchurch: Whitcoulls, 1976); Lynda Bryder, 'History of Medicine in Australia and New Zealand', in The Oxford Handbook of the History of Medicine, ed. Mark Jackson (Oxford: Oxford University Press, 2013), 302-21; Rex Wright-St. Clair, A History of the New Zealand Medical Association: The First Hundred Years (Wellington: Butterworths, 1987); Pamela Wood, Dirt: Filth and Decay in a New World Arcadia (Auckland: Auckland University Press, 2005); Barbara Brookes, 'The Making of a Controversy: History, Medicine and Politics', in The Cartwright Papers: Essays on the Cervical Cancer Inquiry 1987-88, ed. J. Manning (Wellington: Bridget Williams Books, 2009), 100-17; Lynda Bryder, ed., A Healthy Country: Essays on the Social History of Medicine in New Zealand (Wellington: Bridget Williams Books, 1991); Catharine Coleborne, 'Health and Illness, 1840s-1900s', in The New Oxford History of New Zealand, ed. Giselle Byrnes (Auckland: Oxford University Press, 2009); Dow, Safeguarding the Public Health; Michael Belgrave, 'The Rise of the Health Professional in New Zealand, 1860-1939', in A Healthy Country: Essays on the Social History of Medicine in New Zealand, ed. Lynda Bryder (Wellington: Bridget Williams Books, 1991), 7-25.

16 For example, Bernard Myers, The Reminiscences of a Physician (Wellington: A. H. \& A. W. Reed, 1949); Elaine Grundy, Who'd Marry a Doctor? A Chatham Islands Casebook (Christchurch: Whitcombe and Tombs, 1968); Dorothea Joblin, Harvey Come Quick: The Story of the Little Doctor of Waverley (Auckland: Paul's Book Arcade, 1963); Doris Gordon, Doctor Down Under 1890-1956 (London: Faber, 1957); R. Burns Watson, The Doctor Must Get Through: 50 Years a General-Practitioner-Surgeon (Wellington: Reed, 1971). 
New Zealand and provided statistics for further analysis. ${ }^{17}$ Institutional histories such as Maclean's focus on the changing nature of medical theory and practice. However, they often ignored the elements and nature of care, producing a top-down history that overlooks the experience of health and wellness in its myriad forms.

By the 1970s, a new wave of historians aimed to broaden the scope of this research and include people previously marginalised, such as women and patients. ${ }^{18}$ In New Zealand, during this period, historian Laurie Gluckman, although still largely committed to doctors' stories, moved closer towards this approach. ${ }^{19}$ Through a series of potted biographies, Gluckman, in his investigation into New Zealand's medical services prior to 1860 , reveals an interest in native medicinal plants expressed by European doctors and scientists. Biographies of medical practitioners, such as those presented by Gluckman, can uncover the multiple perceptions, viewpoints, and contested nature of medico-botanical knowledge in New Zealand and provide excellent insight into the movement, process of exchange, and adaptation of knowledge. ${ }^{20}$

\section{'Casting a wide net': The advantages of weaving multiple sources}

It is possible to recreate connections between health and medicinal plants, extend research, and include aspects of society and people otherwise overlooked in historical scholarship by using diverse or little-used primary and secondary source material. This section gives specific examples of the benefits of using such source material and shows what they can reveal about the use of medicinal plants in colonial New Zealand. Traditional and obvious primary sources often analysed by medical historians include 'herbals' - manuscripts that describe and detail the uses of medicinal plants - and pharmacopoeia. ${ }^{21}$ Typically written by male medical practitioners, herbals and pharmacopoeia shed light on the

17 Maclean, Challenge for Health; Wilson, A Hundred Years of Healing; Bennet, Hospital on the Avon; Hercus and Bell, The Otago Medical School.

18 Susan Reverby and David Rosner, "Beyond the Great Doctors" Revisited: A Generation of the "New" Social History of Medicine', in Locating Medical History: The Stories and Their Meanings, ed. Frank Warner Huisman and John Harley (Baltimore, MD: Johns Hopkins University Press, 2007), 167-94. The Social History of Medicine, published on behalf of the Society for the Social History of Medicine, started in 1988 and is a prominent forum for this research: shm.oxfordjournals.org/.

19 Gluckman, Tangiwai.

20 Bronwyn Dalley and Bronwyn Labrum, Fragments: New Zealand Social and Cultural History (Auckland: Auckland University Press, 2000), 4.

21 The historian Agnes Arber describes herbals as books or manuscripts that contain the names and descriptions of plants along with their properties and virtues. Agnes Arber, Herbals: Their Origin and Evolution: A Chapter in the History of Botany, 1470-1670, 2nd ed. (Cambridge: Cambridge University Press, 1938), 14. 
professional side of health advice and medico-botanical knowledge. In contrast, non-traditional sources, such as personal collections of medical 'receipts' (recipes), uncover lay attitudes to health and healing and the use of medicinal plants. In colonial New Zealand, new editions of British herbal manuals, such as William Turner's A New Herball (1564) and John Gerard's Herball (1597), were advertised for sale by local bookshops and contained information on plants that were being introduced and dispersed in the colony at a rapid rate. ${ }^{22}$ These texts often contained information from, or were English translations of, much earlier works such as De Materia Medica, written by the Roman physician Pedanius Dioscorides between AD 50 and 70. They included plants from around the Greek and Roman world as well as Chinese plants that entered Europe through the Silk Road - an extensive network of trade routes established during the Han Dynasty (BC 206 - AD 220) used by Arab, Indian, Persian, and Roman traders. ${ }^{23}$

While herbals such as Gerard's and Turner's remained in circulation, by the nineteenth century they were gradually being replaced in medical universities and centres of learning in Britain and America by officially sanctioned pharmacopoeia and pharmacological textbooks. Most of New Zealand's earliest physicians were educated in British universities and, from 1870 to 1920 , as the subject of pharmacology became increasingly defined, doctors in New Zealand developed a medical curriculum that maintained strong ties with British, particularly Scottish, institutions where the study of plants was an important component of the medical curriculum. ${ }^{24}$ For example, in 1883 Edinburgh graduate Dr John Macdonald was appointed Professor of Materia Medica at the Otago Medical School, and taught the subject for 17 years in what doctorhistorians Charles Hercus and Gordon Bell describe as 'the Edinburgh tradition' ${ }^{25}$ Macdonald relied heavily on William Hale-White's textbook, Materia Medica, Pharmacology, Pharmacy and Therapeutics, originally published in London

22 Advertisements for these can found in early New Zealand newspapers accessible through Papers Past, an online repository of 84 New Zealand newspapers and periodicals published between 1839 and 1945: paperspast.natlib.govt.nz/cgi-bin/paperspast; Marcus Woodward, Gerard's Herball: The Essence thereof distilled by Marcus Woodward from the Edition of Th. Johnson, 1636 (London: Spring Books, 1964), xv-xvii.

23 Jane Kilpatrick, Gifts from the Gardens of China (London: Frances Lincoln, 2007), 15-16; British Pharmacopoeia, published under the direction of the General Council of Medical Education and Registration of the United Kingdom, Pursuant to the Medical Act, 1858 (London: Spottiswood \& Co. for the Medical Council, 1885), 126; Dioscorides included Chinese day lilies, Hemerocallis lilioasphodelus in De Materia Medica and Chinese medicinal rhubarb, Rheum palmatum, became and remained a popular medicine in western countries up until the late nineteenth century. See Maggie Campbell-Culver, The Origin of Plants: The People and Plants That Have Shaped Britain's Garden History (London: Transworld Publishers, 2004), 18-33.

24 About half of New Zealand's earliest doctors, 82 out of 166 registered in 1867, gained their degrees at English universities, while the majority of the remainder qualified at Scottish institutions: Belgrave, “"Medical Men" and "Lady Doctors" The Making of a New Zealand Profession, 1867-1941', (PhD diss., Victoria University of Wellington, 1985); Gluckman, Tangiwai; Wilson, A Hundred Years of Healing; John Armstrong, 'The Common-Health and Beyond: New Zealand Trainee Specialists in International Medical networks, 1945-1975' (PhD diss., University of Waikato, 2012).

25 Hercus and Bell, The Otago Medical School, 264; Dorothy Page, Anatomy of a Medical School: A History of Medicine at the University of Otago, 1875-2000 (Dunedin: Otago University Press, 2008), 31. 
and Philadelphia in 1892. His 'orthodox' teaching of the subject involved visual recognition of plants, memorisation of lists of drugs, and, assisted by the hospital dispenser, the preparation of pills, ointments, and potions in the hospital dispensary. ${ }^{26}$

An analysis of nineteenth-century pharmacopoeia and pharmacological textbooks such as Hale-White's reveals that the plants used and prepared by doctors during the period of their publication can also shed light on broader influences, developments, and trends in the field. For example, the third American edition of Hale-White's text, published in 1895, defined pharmacology as 'the study of materia medica and therapeutics including the origins, history, properties and uses of drugs and medicines'. Pharmacy is 'the art of preparing drugs in a form suitable for use as remedial agents, and of dispensing them' ${ }^{27}$ According to this book, doctors should never attempt pharmacy; they should, however, be familiar with chemical processes so they may judge intelligibly the services provided by chemists. ${ }^{28}$ This pragmatic advice would have appealed to doctors in New Zealand, where boundaries between chemists and doctors were more fluid than those in Britain. ${ }^{29}$

A large number of inorganic compounds and elements is included in HaleWhite's textbook, such as arsenic, mercury, copper, and zinc. ${ }^{30}$ Yet, the majority of medicinal compounds in Hale-White's text are 'organic vegetable materia medica'; 243 plants are described as pharmacopoeial vegetable drugs. For every plant, the textbook provides a brief botanical classification and description, lists the forms in which the drug is generally used, and explains the actions and therapeutic qualities of the drug. The book's retention of botanical information, and Macdonald's expectation that all doctors visually recognise popular species, suggests that doctors continued to use plants in their natural or whole form, despite a growing tendency for doctors to isolate constituents and process plants beyond recognition.

26 Hercus and Bell, The Otago Medical School, 278.

27 William Hale-White, Materia Medica, Pharmacy, Pharmacology and Therapeutics, 3rd American ed. (Philadelphia, PA: P. Blakiston, Son \& Co., 1895), 9.

28 Hale-White, Materia Medica, 11.

29 Belgrave, "“Medical Men"', 287.

30 Arsenic was a powerful caustic used in dentistry to treat dyspepsia and to remove skin growths. Mercury was a powerful antiseptic, also used to relieve skin itching and inflammation of the joints. Copper treated diarrhoea, laryngitis, bronchitis, and tinea tarsi, while zinc was applied to remove external growths. 
Nineteenth-century doctors' attachment and reliance on pharmacopoeiawhich gave scientific weight to the plants that they listed-helped them assert themselves as scientific and progressive. ${ }^{31}$ In contrast, nineteenth-century herbalists retained a loyalty to the old herbals, a practice that helped to define them as different from physicians. Written in the vernacular of the common man as opposed to the scientific terminology of pharmacopoeia, herbals were also increasingly associated with domestic or lay medicine, and while pharmacopoeia converted the early herbals into scientific terms, the translation of this knowledge within domestic medical manuals made this information available to healers in the home.

By the nineteenth century, most western physicians agreed on the basics of health maintenance and, through domestic medical manuals, provided a constant flow of information, translated into popular terms. ${ }^{32}$ Prescriptions in late eighteenthcentury and early nineteenth-century domestic medical manuals were often simple, with crude measurements, such as 'one to two teaspoons of herb' or 'handful of dried plant material'. Unlike official pharmacopoeias, which contain precise and seemingly indisputable advice, early domestic manuals often included anecdotal information and acknowledged a variety of sources. From these texts, healers selected recipes and often combined them with anecdotal information in their own handwritten personal collections of 'receipts'. This combined approach to health care and advice was a distinguishing feature of domestic medicine in New Zealand during the nineteenth and early twentieth centuries

31 See Bishop, 'The Role of Medicinal Plants', 211-48; [Sir Thomas Richard] Fraser, 'An Address Delivered at the Opening of the Section of Materia Medica and Pharmacology', British Medical Journal 2, no. 1075 (1881): 227-30. The British Medical Association in its campaign against 'unscientific' medicines published Secret Remedies: What they Cost and What they Contain in 1909, which provided a scientific analysis of many popular patent medicines, seemingly proving their uselessness and the fraudulent nature of their manufacturers.

32 Henry M. Lyman, Christian Fenger, H. Webster Jones, and W. T. Belfield, eds, The Practical Home Physician and Encyclopedia of Medicine: A Management of Disease; Giving the History, Cause, Means of Prevention and Symptoms of all Diseases of Men, Women and Children and most Approved methods of Treatment with Plain Instructions for the Care of the Sick, Australasian Edition ([Canada]: The World Publishing, c. 1880); John Harvey Kellogg, Ladies' Guide in Health and Disease (London: International Tract Society, 1895); Edward Foote, Plain Home Talk: Embracing Medical Common Sense, About the Human System, the Habits of Men and Women, the Causes and Prevention of Disease, Our Sexual Relations and Social Natures, Embracing Medical Common Sense, Applied to Causes, Prevention, and Cure of Chronic Diseases, the Natural Relations of Men and Women to Each Other, Society, Love, Marriage, Parentage Etc. (New York: Murray Hill, 1873); Alvin Wood Chase, Dr. Chase's Third, Last and Complete Receipt Book and Household Physician, or, Practical Knowledge for the People, from The Life-Long Observations of the Author, Embracing the Choicest, Most Valuable and Entirely New Receipts in Every Department of Medicine, Mechanics, and Household Economy; Including a Treatise on The Diseases of Women and Children, in fact, The Book for the Million, with Remarks and Explanations which adapt it to the Every-Day Wants of the People, Arranged in Departments and most Copiously Indexed (Dunedin: Malcolm \& Grigg, 1887); O. Phelps Brown, The Complete Herbalist, or, The People their own Physicians by the use of Nature's Remedies Describing the Great Curative Properties Found in the Herbal Kingdom (Jersey City, NJ: The author, 1867). 
and made domestic health care fluid and adaptable, necessary characteristics in a colonial environment without a developed health infrastructure and with isolated settlements.

In colonial New Zealand, domestic medicine or medical care given in the home played a vital and important role. It was a selective and subjective system that combined numerous philosophies and approaches. As well as medical regimes and lifestyle advice, domestic healers used medicinal plants with which they were familiar - species introduced from their homelands - while they experimented with native plants growing in their immediate environment. ${ }^{33}$ Evidence of this can found in colonial domestic health guides and colonists' handbooks.

As the extent of colonisation increased and as discourse on the influence of climate upon health assumed prominence, writers produced manuals intended specifically for New Zealand emigrants. ${ }^{34}$ Colonial handbooks and guides, such as the second edition of Brett's Colonists' Guide published in 1897, encouraged emigrants to learn simple first aid, travel with medicine chests, and obtain handbooks on domestic medicine..$^{35}$ For example, as late as 1897, Brett's guide suggests learning how to bleed, set a broken limb, and bind wounds. ${ }^{36}$ It also included a small but comprehensive section on homeopathic medicines.

Most nineteenth-century medical manuals were written by male doctors and the information they contained, although less structured and ordered than university texts, was that advocated and practised by educated male physicians. For example, by the 1880s, domestic medical manuals reflected the widespread acceptance in medical institutions of scientific theory and analysis by including discrete sections on anatomy and physiology, and by recommending scientifically tested plant-based remedies and patent medicines. ${ }^{37}$ However, alternative sources, such as personal collections of medical recipes, show that the use of medicinal plants by domestic healers often went beyond that which was advocated by scientific medical curricula or pharmaceutical research'evidence' was broad and evaluated in relation to factors such as efficacy,

33 Medicinal plants were important and integral components of domestic health care, often deemed safer than the inorganic compounds containing arsenic and mercury that many doctors relied on. Ever since domestic medicine was described as a distinct system by early authors such as William Buchan, it has been proclaimed safer than that prescribed by a physician. William Buchan, Domestic Medicine; or, the Family Physician (Philadelphia, PA: R. Aitken, 1774), ix-xvii.

34 Anonymous, All About New Zealand: Being a Complete Record of Colonial Life, facsimile ed. (Christchurch: Kiwi Publishers, 1996); John Broadbent, The Australian Botanic Guide, Being a Family Handbook of Botanic Treatment (Melbourne: Centennial Printing and Publishing, c. 1880); John Hill Burton, The Emigrant's Manual. New Zealand, Cape of Good Hope and Port Natal [NZ sections only] (Edinburgh: William and Robert Chambers, 1851), accessed July 2014, www.enzb.auckland.ac.nz/document? wid=2951 \&page=1\&action=null.

35 Thomas Wilson Leys, ed., Brett's Colonists' Guide and Cyclopaedia of Useful Knowledge (Auckland: H. Brett, 1897).

36 Leys, Brett's Colonists' Guide.

37 Kellogg, Ladies' Guide in Health; Foote, Plain Home Talk; Chase, Dr Chase's ... Receipt Book. 
popularity, monetary value, testimony, and authority. ${ }^{38}$ Experimentation, experience, and anecdotal information remained important indicators of worth. Exploring the use of medicinal plants by domestic healers, therefore, requires a broad and overlapping methodological approach.

Unlike published medical material, personal collections of medical 'receipts' can reveal women's perspectives and a system of health care otherwise unrecorded. ${ }^{39}$ The crinkled paper and splattered pages of notebooks, such as that illustrated in Figure 1, used to collect seemingly miscellaneous household information, conjure images of 'kitchen physic', and reveal anxieties and concerted attempts to stay healthy and mitigate sickness. Collections of medical 'receipts' were an essential part of the 'domestic medical curriculum' that guided domestic healers and made their opinions, assessment, and use of medicinal plants different from that of doctors, who relied primarily on pharmacopoeia.

This is evident with the biography of Elizabeth Jane Locke (1849-1942) and her husband Frederick Joseph (1847-1914), who arrived from Guernsey at Port Chalmers (Otago) on 16 February 1873. They brought with them five books for use in New Zealand that contained medicinal 'receipts' collected by Jane, who had worked as a cook at Castle Eden in County Durham prior to their departure. ${ }^{40}$ The earliest, dated 1739-40, includes plants used routinely by British practitioners, such as liquorice, opium, and tansy. It also includes remedies deemed as 'folk' by nineteenth-century doctors, such as the following cure for 'fits':

Take earth moles just as they are taken out of the earth, then dry them in an oven with the hair, blood, guts and everything till they powder very fine, let the person or the child take as much as will lie upon a sixpence three times a day before they expect to fit or any symptoms of fitting are coming and to repeat until the changing moon, but be sure never to take it if the fits are upon them. When the moles are taken out of the oven they should be hung in a paper bag and so powdered when you want them. ${ }^{41}$

\footnotetext{
38 Hocken Library, Dunedin, Archives and Manuscripts, AG-561-04, Dorothy Harvey, Book of Receipts 1739-40; AG-561-06, Recipe Book (1810-28); AG-561-07, Recipe Book inscribed 'Albenia Tathwell 1828' (c. 1800-35); AG-561-08, Recipe Book (n.d.); Hamilton City Library Archives, MS, 190, 1881, William Rysdale, papers.

39 Elaine Leong and Sara Pennell, 'Recipe Collections and the Currency of Medical Knowledge in the Early Modern "Medical Marketplace"', in Medicine and the Market in England and its Colonies, c. 1450 - c. 1850, ed. Mark S. R. Jenner and Patrick Wallis (Basingstoke: Palgrave Macmillan, 2007), 133-52.

40 Hocken Library, Dunedin, AG-561-04, Dorothy Harvey, Book of Receipts 1739-40; AG-561-06, Recipe Book (1810-28); AG-561-07, Recipe Book inscribed 'Albenia Tathwell 1828' (c. 1800-35); AG-561-08, Recipe Book (n.d.).

41 Hocken Library, Dunedin, AG-561-04, Dorothy Harvey, Book of Receipts 1739-40.
} 


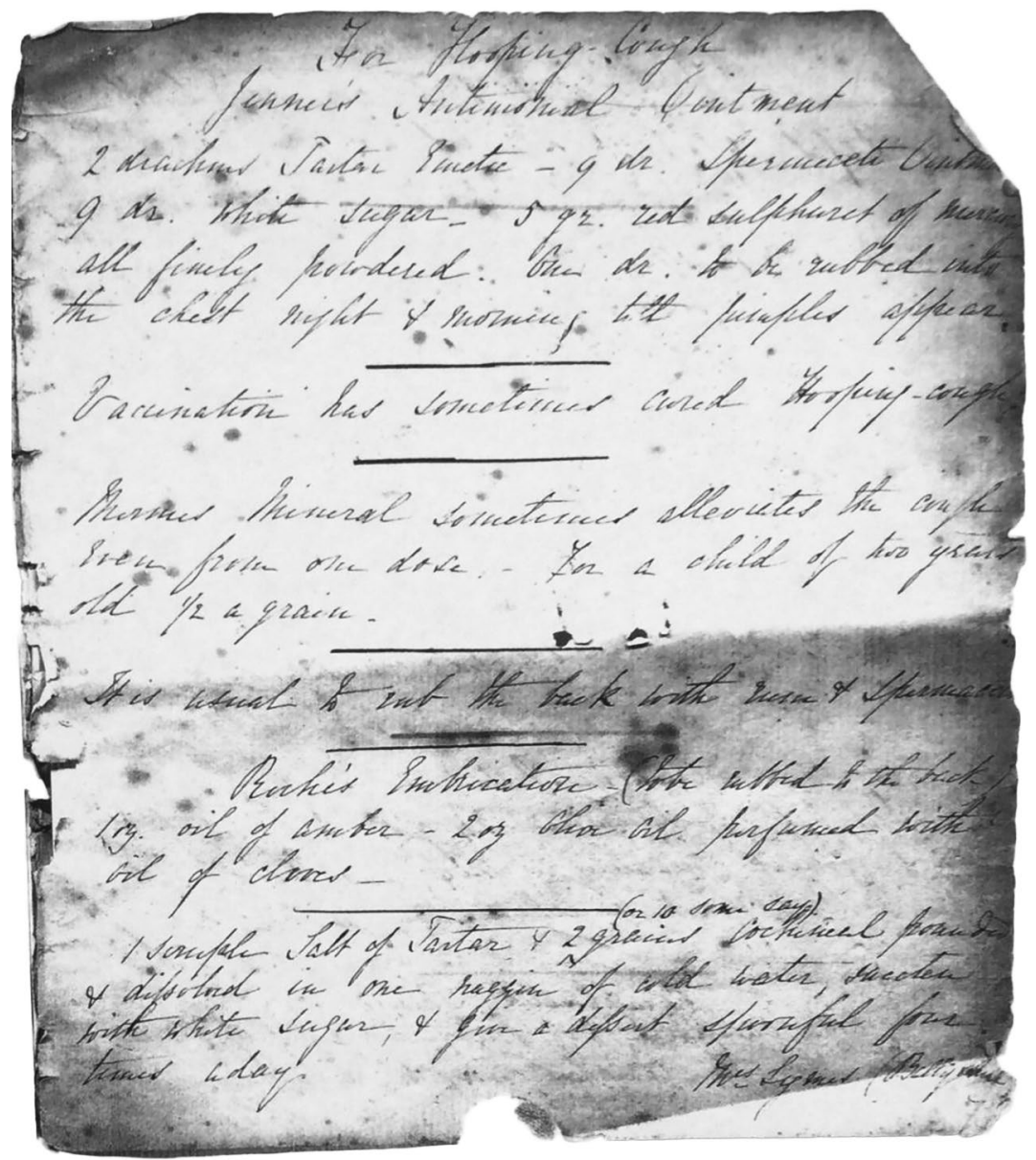

Figure 1: An example of a medical 'receipt' showing notes by the author.

Source: Alexander Turnbull Library, Wellington, MS-Papers-7262, McKain, Douglas Mary, 1789-1873, Diary and commonplace book, transcribed by J. B. Moles.

Dated 1820, the second book in this series includes remedies for rheumatism, biliousness, headaches, jaundice, coughs, colds, weak stomachs, and toothaches - examples of the ailments and illnesses treated regularly during this period. ${ }^{42}$ Directions in this collection are more complicated than the earlier 'receipts' and reflect developments in the pharmaceutical industry. Instructions on how to prepare pills, lozenges, boluses, plasters, and poultices showcase the repertoire of domestic medical care. Household ingredients, such as soap, eggs, 
sugar, and syrup, helped bind and provided a medium for medicinal plants, and unlike the previous collection, the only animal product recommended is hartshorn (powdered red deer antler). ${ }^{43}$

Sources and methodologies applied by garden historians also help to re-establish links among health, the environment, and medicinal plants in historical scholarship. Plant nursery catalogues are becoming increasingly popular sources used by environmental and garden historians to gain insight into the introduction, cultivation, popularity, and distribution of plants. ${ }^{44}$ According to the garden historian Anna Pavord, British and American plant catalogues catered to a growing number of gardeners and remain for some an 'index of horticultural taste'. ${ }^{45}$ In New Zealand, catalogues were produced by nurserymen who established a blooming trade in the colony from as early as 1840. The inclusion or absence of certain plants in catalogues, I argue, can be indicative of their popularity or accessibility. In relation to medicinal plants, that particular species were sold continually by nurserymen indicates they were still in demand and in use throughout the nineteenth century.

Most of New Zealand's early nurserymen trained in Britain, and many hailed from Scotland. ${ }^{46}$ According to Paul Star, they formed an informal network and sent and received plants from right across the British Empire. The historian Alan Hale characterises their life in New Zealand as hard with little reward. Many, he writes, would dig up and burn their stock after a few seasons, choosing instead to sow grass and make a living from agriculture, or wait for London market conditions to improve. However, while New Zealand nurserymen maintained strong ties with Britain, they also created and formed associations among themselves and with other colonies and countries. ${ }^{47}$ Exploring trans-Tasman connections, then, is another avenue for enquiry into medicinal plants.

\footnotetext{
43 Made from the antlers of male red deer, this product was credited with sudorific qualities (it promotes sweating) and was used to treat fever and dysentery. Brown, The Complete Herbalist, 303, 344; Hocken Library, Dunedin, AG-561-06, Recipe Book (1810-28).

44 James Beattie, Jasper M. Heinzen, and John P. Adam, 'Japanese Gardens and Plants in New Zealand, 1850-1950: Transculturation and Transmission', Studies in the History of Gardens \& Designed Landscapes 28, no. 2 (2008): 219-36.

45 These books differ from earlier catalogues produced in seventeenth-century Europe by wealthy European aristocrats to showcase their exotic collections and were first printed in book form in the 1830s. See Anna Pavord, The Tulip (New York: Bloomsbury, 1999), 80; Alice Krinsky Formiga, 'A Short History of the Seed \& Nursery Catalogue in Europe \& the U.S.', scarc.library.oregonstate.edu/omeka/exhibits/show/seed, accessed 25 May 2012.

46 Hale, Pioneer Nurserymen; Robert Cooper, ‘Early Auckland Gardens', Garden History 1, no. 2 (1973): 26-40.

47 Paul Star, 'New Zealand's biota barons: Ecological transformation in colonial New Zealand', ENNZ: Environment and Nature in New Zealand 6, no. 2 (2002): 1-12, environmentalhistory-au-nz.org, accessed 9 May 2014; Sydney Challenger, 'Pioneer nurserymen of Canterbury, New Zealand (1850-65)', Garden History 7, no. 1 (1979): 25-64.
} 
Many plants and seeds introduced into New Zealand came from Australian growers or nurseries, which traded with plant collectors. ${ }^{48}$ New Zealand nurserymen also grew a great number of plants from seeds and cuttings that circulated internally. Nurserymen advertised in national newspapers and many wrote columns to enhance their visibility in the community. For example, Christchurch's first mayor, Scottish nurseryman William Wilson, also known as 'Cabbage' Wilson, wrote a series of articles for the Lyttelton Times entitled 'Calendar of Garden and Farm Operations'. William Swale, a contemporary of Wilson's and also based in Christchurch, contributed to the 'Gardeners' Chronicle' in the same newspaper. ${ }^{49}$ Newspapers, therefore, are equally important sources, being the main forum through which plants and tools were advertised until the 1860s, after which time printed plant catalogues began to be produced in significant numbers.

According to Alice Krinsky Formiga, curator at the University of Oregon, the omission of a medicinal plant section from most American and British catalogues by the mid-nineteenth century reflects a decline in the private cultivation of medicinal plants. ${ }^{50}$ In contrast to Britain and North America, New Zealand catalogues included medicinal plants until the early twentieth century, while evidence in personal correspondence and collections of medical 'receipts' suggest that settlers remained loyal to the remedies made from these plants. A strong culture of domestic healing and the need to propagate medicinal plants in isolated settlements where doctors were scarce and supplies of medicine inconsistent, arguably supported the continued propagation and supply of medicinal plants by New Zealand nurserymen. In 1873, for example, the Martin Brothers of Auckland included in the Herbs, Roots etc. section of their catalogue chamomile, fennel, garlic, horseradish, lavender, rue, rosemary and thyme. ${ }^{51}$ In their 1891 catalogue, D. Hay and Sons of Montpellier Nursery, Auckland, had a Herbs and Miscellaneous Root section in which rue, lavender, thyme, horehound, and horseradish appear. In 1893, Dunedin's George Matthews had an extensive herb section and advertised horehound, hyssop, lavender, rosemary, tansy, wormwood, balm, rue, and thyme. In their Spring 1907 catalogue, Howden and Moncrief of Dunedin included a Sweet and Pot Herbs section in which anise, balm, chamomile, horehound, hyssop, lavender, pennyroyal, rosemary, and rue are listed. ${ }^{52}$

48 Beattie, 'The Empire of the Rhododendron', 241-57, 365-7.

49 Lyttelton Times, 4 December 1852, 7.

50 Formiga, 'A Short History of the Seed \& Nursery Catalogue in Europe \& the U.S.'

51 Alexander Turnbull Library, Wellington, Eph-A-HORTICULTURE-1899-01, Ephemera and horticulture sales catalogues issued by New Zealand plant nurseries, 1870-1899.

52 D. Hay \& Son, Nurserymen: Descriptive Catalogue 1899-1900, With Novelty List. Montpellier Nursery (Established 1855), near Parnell, Auckland, New Zealand (1899); Alexander Turnbull Library, Wellington, Eph-A-HORTICULTURE-1870/1899; 'Messrs Howden and Moncrief's Catalogue', Otago Witness, 11 July 1889, 9, natlib.govt.nz/records/9054854, accessed 21 December 2013. 
References in diaries, letters, and personal correspondence written by New Zealand's colonists can also provide insight into their relationship with, and use of, medicinal plants. These anecdotes may well align with evidence in the scientific literature, such as botanical surveys, strengthening and supporting findings that show the spread of medicinal plants, sometimes as weeds. Plantain, for example, first recorded in New Zealand in 1839, was a particular favourite of healers. It was included in medical recipes and described in medical manuals. ${ }^{53}$ It also appeared in botanical surveys, which describe it as growing readily in various locations and 'quite as general[ly] as in England'. ${ }^{44}$ Watercress, described in early botanical reports as threatening to choke the Avon River in Christchurch, was also reportedly used in cases of eye infections. ${ }^{55}$ The common dock, which according to botanists almost certainly arrived by accident in agricultural seed mixes and quickly spread throughout the colony, was applied to stings and wounds, and used as a blood cleanser. ${ }^{56}$ Combining analyses of scientific reports and personal correspondence ensures the examination of both professional and lay use of plants.

By the 1860s, scientists in New Zealand were producing scholarship designed to assist the colonial government to further economic development. The official journal of the New Zealand Institute (the primary scientific institute during the period, renamed the Royal Society of New Zealand in 1933), The Transactions and Proceedings of the New Zealand Institute, began in 1867 and became a forum for the publication of scientific work. ${ }^{57}$ This journal includes botanical surveys that can be used to help determine the introduction and distribution of medicinal plants as well as the role of the state in medicinal plant trials and experiments. Reports on government endeavours are also contained in the Appendices to the Journals of the House of Representatives, another useful and readily available official source. ${ }^{58}$

53 Murdoch Riley, Māori Healing and Herbal: New Zealand Ethnobotanical Sourcebook (Paraparaumu: Viking Sevenseas N.Z., 1994), 222-5; James Neil, The New Zealand Family Herb Doctor: A Guide to Recipes and Herbal Remedies [first published 1889] (Twickenham: Senate, 1998), 493.

54 Riley, Māori Healing and Herbal, 222-5.

55 Riley, Māori Healing and Herbal, 247; John Armstrong, 'On the naturalized plants of the province of Canterbury', Transactions and Proceedings of the New Zealand Institute 4 (1871), 284-90.

56 Riley, Māori Healing and Herbal, 317-18; Maida Barlow, 'Harrold, Agnes', Dictionary of New Zealand Biography: Te Ara-The Encyclopedia of New Zealand, www.teara.govt.nz/en/biographies/1h10/harroldagnes, accessed 11 May 2014; Barbara Harper, Petticoat Pioneers: South Island Women of the Colonial Era, vol. 3 (Wellington: A. H. \& A. W. Reed, 1980), 94-7.

57 In collaboration with the National Library of New Zealand Te Puna Mātauranga o Aotearoa, the Royal Society digitised their original volumes, which are now available online. The original volumes are held at the Alexander Turnbull Library. The Transactions and Proceedings of the Royal Society of New Zealand, rsnz.natlib. govt.nz.

58 Appendices to the Journals of the House of Representatives (AJHR), atojs.natlib.govt.nz/. 
As the historian Karen Harvey points out, objects can be valuable sources that can enrich historical research, while domestic medical commodities, such as sickroom requisites, and patent and proprietary medicines, can also provide insight into domestic medical culture. ${ }^{59}$ An analysis of patent and propriety medicines, for example, can reveal medical fashions and trends often difficult to assess by other means. Examining their ingredients provides insight into the plants processed by the pharmaceutical industry at the time of production. Table 1, for example, presents the plants included in two popular patent medicines, Holloway's Pills and Page Woodcock's Wind Pills. ${ }^{60}$ While some patent medicines combined only two or three ingredients, others combined every plant known to possess similar qualities, in an approach that mirrored domestic medical practices.

Table 1: Compound formulas published in The Chemists' and Druggists' Diary (1881).

\begin{tabular}{|l|l|l|l|}
\hline Holloway's Pills & Grammes & Page Woodcock's Wind Pills & Ounces \\
\hline Sulphate of Soda & 0.20 & Extract of gentian root & $10 \mathrm{oz}$ \\
Saffron & 0.20 & Extract of camomile flowersPowder of extract of aloe & $7 \mathrm{oz}$ \\
Pepper & 0.45 & Powder of Turkey rhubarb roots & $4 \mathrm{oz}$ \\
Rhubarb & 1.70 & Powder of Jamaican ginger & $4 \mathrm{oz}$ \\
Socotrine aloes & 4.00 & Powder of gum myrrh & $2 \mathrm{oz}$ \\
& & Powdered Castile soap & $2 \mathrm{oz}$ \\
& & Powder of ipecacuanha & $4 \mathrm{oz}$ \\
& & Compound extract of colocynth & $1 \mathrm{~d} / 2 \mathrm{oz}$ \\
& & Essential oil of peppermint & $2 \mathrm{oz}$ \\
& & Essential oil aniseed & $1 \mathrm{drachm}$ \\
& & & $1 \mathrm{drachm}$ \\
\hline
\end{tabular}

Source: The Chemists' and Druggists' Diary (London: Chemist and Druggist, 1881): 88-9.

Similarly, the marketing and promotion of these medicines often reflected popular opinions relating to medicine and consumerism. In nineteenth-century New Zealand, the popularity and consumption of patent and proprietary medicines were great. Increasing tariffs on patent and proprietary medicines from the 1880s onwards caused constant concerns to wholesalers and consumers, and fed debate on the worth of patent medicines. ${ }^{61}$ While some manufacturers claimed that the consumption of patent medicines was a sign of wealth and 'civility', others argued that it was an expression of ignorance. ${ }^{62}$ Regardless,

59 Karen Harvey, ed., History and Material Culture: A Student's Guide to Approaching Alternative Sources (London: Routledge, 2009), 6.

60 Chemist and Druggist of Australasia, number and edition unknown (1881), 88-9.

61 Thames Star, 29 August 1900, 4; Auckland Star, 31 May 1888, 8; Wanganui Chronicle, 29 August 1900, 2. 62 In 1893, a correspondent writing for the Otago Daily Times reported the opinion of H. R. Packard of Chicago, who proposed there could be no better test of prosperity and civilization of a community than the quantity of patent medicines it consumed. Arguing this point, the columnist Thackeray James wrote that 'in the colonies the ignorant and half-educated have more money at [their] command than the same elsewhere and can afford themselves luxuries - patent medicines to wit'. Chemist and Druggist of Australasia, 8, no. 4 (1893), 8-9. 
for many of New Zealand's domestic healers, patent medicines were useful and readily available, and their pervasiveness arguably suggests a perception of respectability associated with their use.

By the turn of the twentieth century, several doctors, incensed by what they claimed was false advertising and swindling by unscrupulous patent medicine manufacturers, sought to control the sale and manufacture of patent and proprietary medicines. The Quackery Prevention Act (1908), advocated by many doctors, was passed to assert such controls. ${ }^{63}$ The Act stated that it was an offence to publish false information relating to the ingredients, composition, and efficacy of any medicine or medical practice. It fed into, and drew upon, rhetoric expressed in such publications as Secret Remedies: What they Cost and What they Contain (1909), issued by the British Medical Association, that supported scientific analysis as a measure of efficacy. In response, manufacturers of patent and propriety medicines - who were not required to disclose the ingredients of their medicines until 1946-advertised their drugs as 'scientific', despite the absence of either standardised tests or controls. The advertisements for Gatenby's Blue Flag Liver Cure (Figure 2), for example, described it as scientific. However, proof of its reliability and efficacy appeared to stem solely from the experience of hundreds of men, women and children' ${ }^{64}$

By the late nineteenth and early twentieth centuries, as the production of patent and proprietary medicine grew exponentially, the production of medical implements and medicines also increased. Evidence for this can be found in advertisements from the period. ${ }^{65}$ Well-known manufacturers produced domestic treatments and associated implements and presented them in a way that supported the value and respectability of domestic medical practices. Analysing advertisements provides another little-used line of enquiry into how plants were used and featured in domestic health practices.

63 'Quackery Prevention Bill Committee', AJHR (1907): I-14, 1-70.

64 Wanganui Herald, 7 February 1903, 4.

65 In a New Zealand Farmers' Trading Co. catalogue distributed in 1921, a selection of sickroom requisitesincluding eye baths, enema kits, thermometers, ear syringes, and douche cans - showcase the nature and extent of domestic care. Two pages dedicated to patent medicines indicate the prevalence and continued popularity of these medicines. Farmers' Trading Company Limited, Catalogue May 1931 (Auckland: The company, 1931), $60-3,237$. 


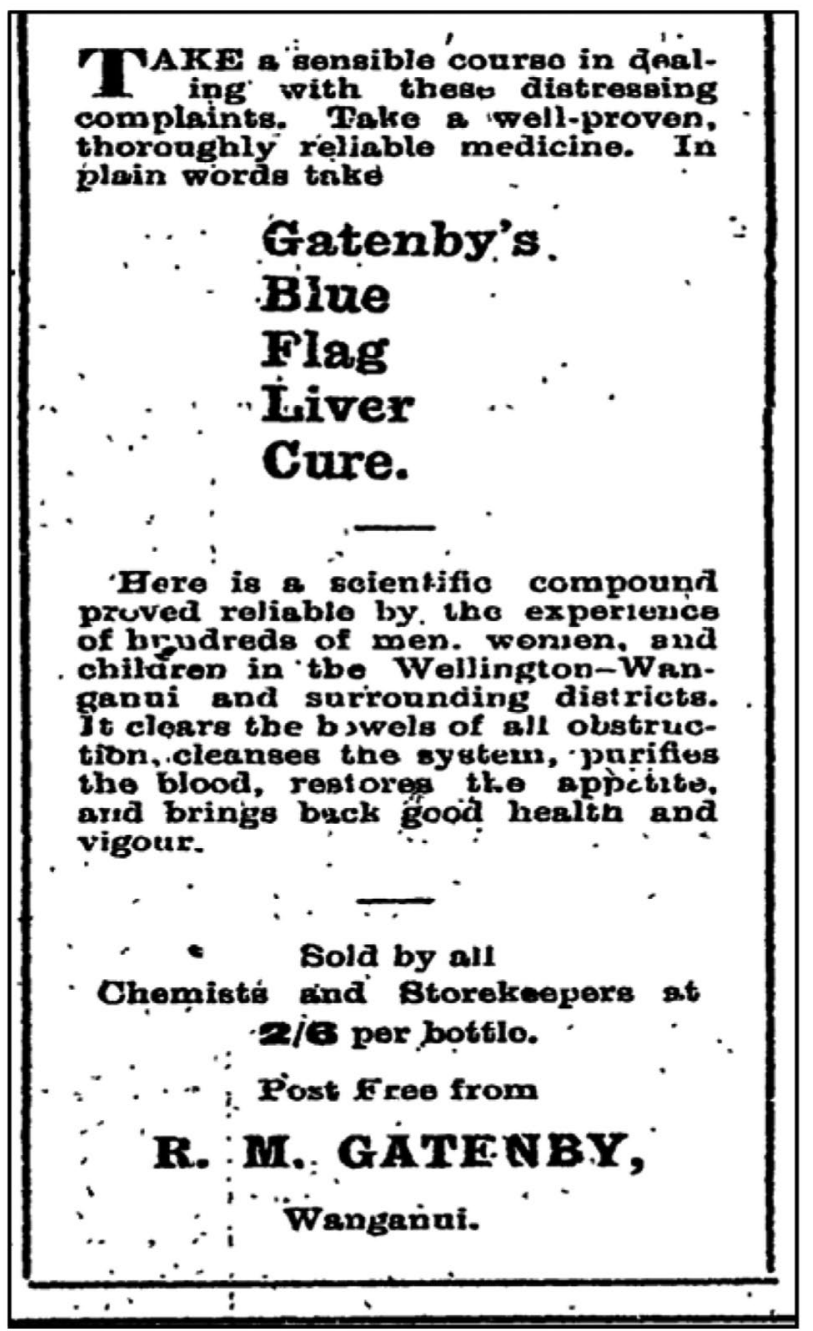

Figure 2: Advertisement for Gatenby's Blue Flag Liver Cure.

Source: Wanganui Herald, 7 February 1903, p. 4.

\section{Conclusion}

Medicinal plants played an integral role in New Zealand's colonial medical and botanical culture. These plants were studied and used by different medical practitioners; investigated and trialled by botanists; and cultivated, sold, and exchanged by nurserymen. Studying them, therefore, affords an opportunity to link aspects of medical history and garden history. It permits researchers 
to collate a number of scattered and fragmented references in primary and secondary sources, and with that recollation, enable them to explore connections among healers, botanists, pharmacists, gardeners, and others.

For centuries, gardens and plants have been studied from various perspectives and garden historians have become adept at referring to, and traversing, the literature and ephemera produced. Exploring the history of medicinal plants affords a unique opportunity to contribute to historiographies of medicine, gardens, the environment, pharmacy, and science. It requires an overlapping and inclusive methodology that involves both qualitative and quantitative analyses of a wide range of source material, and which also encourages an interdisciplinary approach to research. An eclectic collection of primary and secondary sources can corroborate and strengthen findings and encourage cooperation between scholars from seemingly different disciplines such as science and history. Blurring disciplinary lines creates new avenues for enquiry and widens the appeal of garden history. 
This text is taken from International Review of Environmental History, Volume 2, 2016, edited by James Beattie, published 2016 by ANU Press, The Australian National University, Canberra, Australia. 